\title{
Antyspołeczne zachowania dzieci i młodzieży z rodzin dotkniętych przemocą domową
}

\section{Zaburzenia w zachowaniu i osobowość antyspołeczna}

Osobowość antyspołeczna to diagnoza charakteru. Określamy tak kogoś, kto żyje w sposób niezgodny z przyjętymi normami w danej kulturze czy środowisku. Osobę, która nie stosuje się do zwyczajów i stylu zachowania akceptowanych w danym miejscu i nie widzi w tym problemu, przeciwnie: uważa, że są bezwartościowe, ograniczają wolność, a wszyscy wokół bezpodstawnie się „czepiają” lub „nudzą”, odwołując się do priorytetów. Niekiedy rozpoznanie osobowości antyspołecznej (dyssocjalnej) utożsamiano z diagnozą psychopatii bądź socjopatii. W związku ze specyfiką objawów zaburzenia niekiedy powstaje skłonność do takiego rozumienia zjawiska, że psychopata to degenerat, kryminalista, człowiek spoza społecznego nawiasu. Bywa, że tak właśnie jest, ale też prawdą jest, iż nie wszystkie jednostki antyspołeczne są całkowicie niedostosowane i wymagają odizolowania ${ }^{1}$.

M. Koźdub, Osobowość antyspołeczna, http://zaburzeniaosobowosci.pl/antyspoleczna.html (09.09.2018). 
Zaburzenie w zachowaniu utrudnia funkcjonowanie dziecka w obrębie różnorodnych wymagań wynikających z konieczności przystosowania się do różnych ról społecznych i ustosunkowania się do samego siebie, rodzeństwa, kolegów, rodziców i nauczycieli. Wraz z rozwojem potrzeb i sprawności zmieniają się interakcje $\mathrm{z}$ różnymi osobami z otoczenia społecznego - zmieniają się nie tylko wymagania dziecka w stosunku do tych osób, ale równocześnie oczekiwania wszystkich partnerów interakcji w stosunku do zaburzonego emocjonalnie dziecka. Tak więc zmiany rozwojowe przekształcają samą naturę zaburzenia. O ile na wcześniejszych etapach rozwojowych zaburzenie przejawia się w granicach indywidualnego problemu dziecka i jego najbliższego otoczenia, o tyle w miarę dorastania rozwija się w kierunku problemu społecznego. W ten sposób zaburzenie emocjonalne przekształca się w zjawisko określane jako niedostosowanie społeczne. Inaczej: niedostosowanie zostało wyzwolone przez zaburzenie, które w miarę dalszego rozwoju staje się składową częścią problemu niedostosowania. Ta transformacja zaburzenia emocjonalnego w niedostosowanie społeczne jest powodem wymuszonych, dodatkowych obowiązków wychowawców, a teoretykom wychowania narzuca konieczność wypracowania zasad i metod wychowania terapeutyczno-resocjalizująceg ${ }^{2}$. Tak określone zaburzenie emocjonalne obejmuje wiele różnych złożonych cech i wzorów (dziedzin) funkcjonowania. Chociaż zaburzenie emocjonalne nie jest tożsame $\mathrm{z}$ niedostosowaniem społecznym, to jest ściśle z nim powiązane, stanowiąc najczęściej jego przyczynę lub jego wstępny etap. Tak więc zaburzenie emocjonalne stanowi psychologiczną komponentę niedostosowania społecznego, które jest zjawiskiem bardziej złożonym, składającym się z czynników psychologicznych, ale mamy też wyraźny aspekt socjologiczny³.

Poznawanie wpływów wychowawczych rodziny narzuca istotne, a równocześnie złożone i trudne pytanie: jakie postawy rodzicielskie, stymulujące wszechstronnie zarówno indywidualny, jak i społeczny rozwój dziecka, tak ukształtują jego osobowość, aby adekwatnie funkcjonowało w różnorodnych rolach społecznych? Dane empiryczne z psychologii familiologicznej wskazują, że szczególnie korzystna wychowawczo postawa zapewni dziecku poczucie bezpieczeństwa, akceptację jego indywidualności, ale również dostosowaną do jego poziomu rozumną swobodę oraz poczucie niezależ-

2 B. Urban, Zaburzenia w zachowaniu i przestępczość młodzieży, Kraków 2000, s. 17.

B. Urban, Zaburzenia w zachowaniu i przestępczość młodzieży, dz. cyt., s. 18. 
ności. Stworzenie stymulujących warunków rozwojowych jednostki opiera się na realizowaniu jej podstawowych (głównie emocjonalnych) potrzeb psychicznych, sprowadzających się w okresie dorastania do zaspokojenia potrzeby miłości - zarówno bycia kochanym, jak i okazywania pozytywnych uczuć, uznania oraz samorealizacji. Taki komfort psychiczny zapewnia środowisko rodzinne o właściwej atmosferze wychowawczej, powstałej dzięki pozytywnym postawom rodzicielskim, maksymalizując możliwości rozwojowe młodzieży, a jednocześnie całego systemu ${ }^{4}$. Mówi się o rodzinie patchworkowej - wielokrotnie „montowanej” i „demontowanej”, złożonej z wielu różnych podsystemów składających się z rodzica, jego partnera (lub zmieniających się partnerów), dzieci pochodzących z aktualnego i poprzednich związków. Często przyczyną takich rotacji w grupach rodzinnych są dysfunkcje członków rodziny (choroba alkoholowa, uzależnienie od narkotyków i inne uzależnienia, przemoc itd.). Warto podkreślić, że spotykane obecnie przekształcenia rodzin mają swoje źródło także w przemianach społeczno-ekonomicznych otoczenia rodziny. Rodzina w dobie globalizacji jest coraz mniej trwała. Obserwujemy obecnie nasilające się zjawisko migracji, którego przyczyny tkwią w czynnikach ekonomicznych, kryzysach politycznych, niepokojach kulturowych, działaniach wojennych itp. Celem migracji jest poprawa bytu materialnego rodzin, ich bezpieczeństwa, zwiększenia szans kulturowych i ekonomicznych, poprawa pozycji w satysfakcji społecznej członków rodzin. Często jednak te dążenia rozdzielają rodziny i ostatecznie powodują ich rozbicie, nasilają kryzys ${ }^{5}$.

Zaburzenia w wychowaniu i rozwój antyspołeczny są swego rodzaju procesem, który w cyklu swoich negatywnych postaw, braku przekazywanych wartości i wymienionych korzystnych postaw wychowawczych ukierunkowany jest tylko w jedną negatywna stronę. Ciężko jest zmienić swój światopogląd, nastawienie, zaufanie do innych, kiedy przez lata człowiek „karmiony” jest wrogością i nienawiścią w domu, w którym się wychował.

4 J. M. Wolińska, Agresywność młodzieży. Problem indywidualny i społeczny, Lublin 2000, s. 42.

5 G. Kudlak, Instytucjonalna resocjalizacja nieletnich. Wyzwania i perspektywy rozwoju, Warszawa 2016, s. 136. 


\section{Patologia rodziny i skutki braku więzi emocjonalnych}

Patologie społeczne to zjawiska społecznego zachowania się jednostek i grup oraz funkcjonowania instytucji społecznych, pozostające w sprzeczności z wartościami i zasadami akceptowanymi przez dane społeczeństwo. Wśród przejawów dysfunkcji organizmu społecznego rozróżnia się patologię społeczną indywidualną, gdy nosicielami i przekaźnikami negatywnych cech i zachowań są jednostki, oraz patologię życia zorganizowanego, gdy człowiek jest głównym przedmiotem ujemnych oddziaływań struktur społecznych, stosunków międzyludzkich. Do najważniejszych zjawisk patologii społecznych zalicza się: przestępczość, pijaństwo i alkoholizm, narkomanię, prostytucję, patologię rodziny (m.in. sieroctwo społeczne, rozwody) oraz patologię struktur organizacyjnych (np. kliki, nepotyzm, niekompetencję, niejasny podział obowiązków i odpowiedzialności między komórkami organizacyjnymi) ${ }^{6}$.

Termin „patologia rodziny” jest dość często używany w literaturze pedagogicznej i socjologicznej. Wielu naukowców używa obok terminu „patologia” również innych, takich jak: dewiacja, dezorganizacja, zjawiska patogenne, symptomy patologii życia rodzinnego, rodzina zagrożona. Autorzy ci uważają, że rodziny patologiczne nie spełniają prawidłowo funkcji socjalizacyjnej wobec swoich dzieci. Do pełnienia tej funkcji często sami rodzice nie są przygotowani, a ich środowiska życia cechuje duże nasilenie wzajemnie wzmacniających się ujemnie czynników, kształtujących społeczne postawy badanych. Czynniki te tkwią między innymi w strukturze rodziny, braku więzi uczuciowej, nałogach rodziców, braku zaspokojenia potrzeb dzieci na poziomie niezbędnego minimum życiowego, a także w przyzwoleniu rodziców na negatywne zachowania społeczne dzieci, w tym zachowania przestępcze. Przyczyn powstawania takich sytuacji w rodzinach można upatrywać w trudnych warunkach materialnych i mieszkaniowych, które rzutują na zaspokojenie potrzeb biologicznych, rozwojowych i wychowawczych. Konsekwencją tych zjawisk jest przede wszystkim cierpienie członków rodzin, szczególnie kobiet i dzieci. Brak perspektyw na zmianę istniejącej, trudnej sytuacji materialnej i bytowej może doprowadzić do patologii rodzin, przede wszystkim do alkoholizmu. Adolescenci wychowujący się

6 https://encyklopedia.pwn.pl/haslo/patologie-spoleczne;3955029.html (12.09.2018). 
w tego typu środowiskach są pozbawieni wzorców, które mogliby powielać w dorosłym życiu, oraz bodźców do kształtowania wyższych aspiracji ${ }^{7}$.

W dziejach historii przyczyny skłaniające ludzi do wchodzenia wzasięg oddziaływań danych zjawisk patologicznych były wielorakie, a postęp społeczny oraz techniczny rozszerzają ich liczbę. Liczne czynniki sprawcze doprowadzające do zachowań patologicznych nie zostały do końca poznane. Z pewnością możemy do nich zaliczyć m.in. poczucie nierówności oraz gorszego traktowania w otoczeniu. Ponadto zjawiska patologiczne coraz częściej nie występują w wyizolowanych postaciach, a w określonych układach sprzężeń i powiązań. Trzeba nadmienić, że te „stare” zachowania patologiczne występują w nieco zmienionych postaciach, a te "nowe” mogą ludziom skłaniającym się ku nim dostarczać doraźnych subiektywnych korzyści. $\mathrm{W}$ dalszym okresie wikłania się w nie przysparzają ludziom wyjątkowo wiele bólu, cierpień, strat i szkód z degradacją biopsychospołeczną włącznie, nie są też obojętne dla bliższego i dalszego otoczenia społecznego. Sygnalizacja zagadnień związanych ze zjawiskowymi formami patologii społecznej wskazuje, że stanowią one niezmiennie ważne problemy. Wzmiankowane fakty, że współcześnie coraz więcej młodych ludzi znajduje się w zasięgu oddziaływań patologii, wzmagają istotę problemów. To młode pokolenie w niedalekiej przyszłości będzie ukierunkowywało rozwój społeczny i kulturowy ${ }^{8}$.

Każda osoba żyje w danej społeczności i jest na swój sposób szczególnie ważna dla pozostałych, gdyż wyróżnia się swoją indywidualnością. Wiele otrzymuje od społeczeństwa, o ile sama chce coś od siebie dać. Każda jednostka stanowi swoistą siłę, charakter w danej społeczności, dlatego niezwykle ważny jest jej pozytywny rozwój, stanowiący wzmocnienie nie tylko dla niej samej, ale również dla innych. Osoba - jako jednostka natury rozumnej - wyróżnia się w całym świecie przedmiotowych bytów, co stanowi o jej odrębności ${ }^{9}$. Cały ten pozytywny rozwój jest możliwy, kiedy idzie w parze $\mathrm{z}$ odpowiednią socjalizacją $\mathrm{w}$ domu rodzinnym - socjalizacją, która przejawia się nade wszystko wzorcem wychowawczym. Pomimo wszechstronnie i wielokrotnie udowodnionej roli ojca w procesie socjalizacji i wychowania

\footnotetext{
A. Dąbrowska, Rodzina patologiczna w przestrzeni życiowej młodych dorastajacych, „Studia nad Rodziną" (2009), nr 13/1-2 (24-25), s. 205-213.

8 T. Sołtysiak, Zachowania patologiczne młodego pokolenia, w: Resocjalizacja. Zagadnienia prawne, społeczne i metodyczne, red. A. Jaworska, Kraków 2009, s. 51-52.

9 J. Kochel, Wprowadzenie do antropologii pedagogicznej. W kregu pedagogii katolickiej, Opole 2018, s. 18.
} 
dzieci jedynie nieliczne badania z zakresu rodzinnych korelatów zachowań przestępczych odnoszą się do osoby ojca, jego postaw wychowawczych, relacji z dziećmi, a także cech społeczno-demograficznych. $Z$ przeglądu badań nad rolą ojca w genezie zachowań przestępczych jego dzieci, a w szczególności synów, wynika, że:

1. Stan zdrowia, w tym także przewlekłe choroby i obciążenia psychiczne, trwałe kalectwo ojca mają duże znaczenie dla wczesnej demoralizacji nieletniego.

2. Cechy osobowości ojca, takie jak: gwałtowność, wybuchowość, nerwowość, drażliwość, niecierpliwość, bierność, apatyczność, obojętność sprzyjają wczesnej demoralizacji nieletniego.

3. Pozycja zawodowa ojca: im niższa, tym częściej korelat zachowań przestępczych synów.

4. Ojcowie nieletnich sprawców przestępstw to często osoby karane.

5. Ważnym czynnikiem predysponującym do zachowań przestępczych synów jest alkoholizm ojca.

6. Karalność ojców ma związek $\mathrm{z}$ alkoholizowaniem się nieletnich i wczesną przestępczością nieletnich.

Z kolei analiza jakości więzi emocjonalnych w rodzinie wskazuje, że podejmowanie zachowań przestęp czych przez nieletnich następuje częściej w tych rodzinach, w których pożycie rodziców jest konfliktowe i wrogie. Także nieletni doświadczający ze strony rodziców, szczególnie ojca, obojętności i wrogości, czują się do nich mniej przywiązani niż rodzeństwo. Na podstawie analizy wyników badań nad wpływem więzi emocjonalnych $\mathrm{w}$ rodzinie na zachowanie przestępcze nieletnich można stwierdzić, że:

1. Wrogość i obojętność ze strony ojca w stosunku do nieletniego nasila skłonność do podejmowania zachowań niezgodnych z przyjętymi normami.

2. Szczególną rolę w genezie zachowań przestępczych odgrywają lęk przed ojcem oraz poczucie, że ojciec unika i lekceważy syna.

3. Także w genezie przejawów niedostosowania szkolnego znaczący jest negatywny stosunek ojca do nieletniego.

4. Negatywna postawa ojca oraz ogólnie zaburzone kontakty uczuciowe w rodzinie sprzyjają recydywie ${ }^{10}$.

10 M. Sitarczyk, Ojciec w percepcji nieletnich sprawców przestępstw, w: Dziecko jako ofiara i sprawca przemocy. Przestępczość nieletnich, red. B. Gull, M. Wysocka-Pleczyk, Kraków 2009, s. 162. 
Dzieci mające zaburzone stosunki uczuciowe z rodzicami, emocjonalnie odrzucane przez rodziców wykazują często postawę lękową i wrogość. Sytuacja ta sprzyja ich nieprawidłowej socjalizacji i niewłaściwemu ukształtowaniu się osobowości. Stałe poczucie zagrożenia, lęk i wrogość powodują silne napięcia emocjonalne, na które dziecko reaguje agresją lub biernością, a nawet apatią. Sposób reakcji na odrzucenie emocjonalne przez rodziców zależy między innymi od struktury stosunków w rodzinie, od stylu wychowania, wzorów i wartości, jakie rodzina przekazuje dziecku, postaw rodzicielskich, a także właściwości cech osobowych dziecka. Niezaspokojona potrzeba uczuć emocjonalnych wywołuje u dzieci najrozmaitsze urazy psychiczne, powodujące poczucie osamotnienia, które przyczynia się do poczucia własnej niższości i niepełnej wartości. Dzieciom tym nie zależy na osiągnięciu dobrych wyników w nauce, są bierne i niechętne, wykazują mało inicjatywy, a nawet przejawiają apatyczne zachowania. Mają znaczne trudności w koncentrowaniu uwagi na wykonywanym zadaniu, uwaga ich jest rozproszona i mało stabilna, są nadpobudliwe ruchowo. W zachowaniu ich często trudno jest uchwycić istnienie racjonalnych motywów postępowania, wydaje się, że o ich postępowaniu decydują jedynie przypadki i chwilowe emocje. Takie postępowanie wskazuje na zaburzenia emocjonalno-motywacyjnej sfery osobowości. Przejawiają się one przede wszystkim w nieprawidłowym nawiązywaniu kontaktów społecznych i najczęściej przyjmują formy krańcowe: od emocjonalnego „przyklejenia się” do każdej dorosłej osoby do oziębłości uczuciowej w stosunku do drugiego człowieka, a nawet dążenie do izolacji ${ }^{11}$.

\section{Zachowania antyspołeczne dzieci i młodzieży}

Nie będzie przesadą stwierdzenie, że owocem cywilizacji industrialnej i skrajnego liberalizmu, kreującego konsumpcyjny i hedonistyczny styl życia, a także stresu życia i pracy są patologie społeczne, takie jak alkoholizm, „młodzieżowa narkomania”, przestępczość nieletnich i włóczęgostwo. Do groźnych plag społecznych należy również zaliczyć pasożytnictwo społeczne, marnotrawstwo, niefrasobliwość usposobienia i postępowania,

11 S. Cudak, Znaczenie więzi emocjonalnych w rodzinie dla prawidłowego funkcjonowania dzieci, „Pedagogika Rodziny” (2012) nr 2/4, s. 31-39. 
nadmierną wybujałość potrzeb materialnych, zamiłowanie do wygód i rozrywek, lekceważenie wszelkich autorytetów, „obłęd moralny” (moral insanity), dewocyjność kultyczną, wulgaryzm językowy, brak troski o zdrowie oraz przemoc $\mathrm{w}$ rodzinie, $\mathrm{w}$ szkole ${ }^{12}$.

Analizy oficjalnych rejestrów rozmiarów przestępczości współczesnej młodzieży polskiej jednoznacznie ujawniają trzy główne tendencje, które $\mathrm{w}$ znacznym stopniu korelują z tendencjami obserwowanymi od kilkunastu lat w skali globalnej. Pierwsza to systematyczny i znaczący wzrost ogólnych rozmiarów wszystkich rodzajów przestępczości przy stale utrzymującej się przewadze ilościowej przestępstw przeciwko własności materialnej (kradzieży). Druga w ostatnim dziesięcioleciu wyraźnie zaznaczająca się tendencja to obniżanie się dolnej granicy wiekowej nieletnich przestępców. W warunkach polskich zaobserwowano znaczący wzrost liczby przestępstw, których sprawcami są nieletni poniżej trzynastego roku życia. Coraz częściej rejestrowane są też poważne przestępstwa dokonywane przez kilkuletnie dzieci. Tendencja ta decyduje o wzroście zainteresowania problematyką przestępczości przedstawicieli nauk społecznych, tradycyjnie koncentrujących się na „normalnych” zjawiskach społecznych, w tym zjawiskach i procesach ogólnego wychowania. Trzecia tendencja to nagły wzrost przestępstw gwałtownych, opartych na agresji i przemocy skierowanej zarówno wobec rówieśników, jak i osób dorosłych. Ten rodzaj przestępstw rozpowszechnia się i wykracza daleko poza środowiska tradycyjnie określane jako patologiczne (tzw. margines społeczny), a jego tendencja wzrostowa utrzymuje się nawet $\mathrm{w}$ okresach spadku lub zahamowania innych rodzajów przestępstw. Istnieją zatem przesłanki, aby rozmiary i dynamikę młodzieżowej przestępczości gwałtownej traktować jako jedną z głównych cech (tendencję) współczesnej przyszłości ${ }^{13}$.

Analiza psychologiczna zachowań agresywnych wskazuje zwykle na kilka intencji pobić, uszkodzeń ciała, zabójstw:

- pragnienie doznania przyjemności związanej z rywalizacją, ryzykiem i ekscytacją jako stanami ekstremalnymi, porównywanymi do orgazmu, uniesienia związanego z wyrywaniem się ze szponów szarej codzienności i zwykłości. Towarzyszy temu cały zespół prze-

12 B. Hanusik, Przemoc i agresja jako specyficzna forma reakcji człowieka na stres życia i pracy, w: Przemoc dzieci i młodzieży w perspektywie polskiej transformacji ustrojowej, red. J. Papież, A. Płukis, Toruń 1999, s. 81.

13 B. Urban, Zaburzenia w zachowaniu i przestępczość młodzieży, dz. cyt., s. 17. 
żyć charakterystycznych dla hazardzistów typu „rosyjska ruletka”, której normalny człowiek zaakceptować nie jest w stanie. Pragnienie ekscytacji, przeżycia swoistego „święta” i niezwykłości jest tym większe, im częściej tego rodzaju uczucia towarzyszyły aktywności przestępczej nieletniego lub im wcześniej doznał takich stanów;

- przywłaszczenie, które w świadomości napastnika, sprawcy przestępstwa może nastąpić w sytuacji całkowitego unieszkodliwienia ofiary, tj. jej zabójstwo dla zatarcia śladów, ewentualnego rozpoznania itp.;

- zemsta i nienawiść zgeneralizowana na wszystkich ludzi lub na ich pewne urojone krzywdy, których doświadczył sprawca;

- pragnienie władzy idominowania nad słabszym, przerażonym i upokorzonym człowiekiem, wynikające z sadystycznych potrzeb pojawiających się u wielu ludzi wskutek stosowania przez rodziców wadliwych technik socjalizacyjnych ${ }^{14}$.

Niniejsze zachowania antyspołeczne dzieci i młodzieży spowodowane są głównie brakiem odpowiedniego czynnika, jakim jest proces wychowawczy, właściwa socjalizacja. Fundamentalne i nieodzowne wartości społeczne, które powinna kształtować w młodym człowieku rodzina, zatracają się, ulegają destrukcji bądź wcale nie występują. Brak wyostrzonej percepcji: myślenia, widzenia; kształtowania osobowości czy rozwoju: intelektualnego, moralnego, fizycznego, artystycznego u młodego człowieka powoduje, iż zatraca się on w postawie dewiacyjnej. Pomimo negatywnej przeszłości wielu młodych osób należy spojrzeć na przedmiotowy problem z innej perspektywy. Otóż osoby te, mimo iż nie doświadczają czasem właściwego wychowania według przyjętych zasad społecznych i moralnych, uczestniczą w życiu społecznym i dobrze wiedzą, jak powinny wyglądać stosunki interpersonalne oraz mają świadomość konsekwencji swoich zachowań i czynów.

Jednak za każdym razem decyzje podejmuje sprawca. Decyzja taka jest zwykle świadoma, pociąga za sobą ryzyko walki z ofiarą, walki z pościgiem (potencjalnymi organami ścigania przestępczości), wreszcie obejmuje ryzyko walki z samym sobą, gdy pojawiają się wątpliwości co do sensowności lub absurdalności podejmowanego czynu. A gdy się działa w grupie przestępczej, pojawia się obawa o solidarność wewnątrzgrupową, „pękanie”

14 L. Pytka, Niewydarzeni, sfrustrowani, agresywni, w: Przemoc dzieci i młodzieży w perspektywie polskiej transformacji ustrojowej, dz. cyt., s. 69. 
świadków, lojalność, przypisywanie sobie lub zrzucanie odpowiedzialności, „Wrabianie” innych itp. Krótko rzecz ujmując, „przestępca nieletni” nie ma łatwego życia, choć nieco łatwiejsze, jeśli idzie o konsekwencje, niż dorosły. W gruncie rzeczy każdy adolescent ma skomplikowane życie, pełne kryzysów i załamań, frustracji i stresów. Ale nie wszyscy nastolatkowie są na tyle agresywni, aby tę agresję rozładować przez atakowanie i zabijanie przypadkowych przechodniów czy osób z góry upatrzonych na „ofiary”. Każdy adolescent ma świadomość, czym jest życie ludzkie i jakie są konsekwencje zabicia nożem, kijem itp. I choć młody wiek wiele może usprawiedliwić, to przecież nie da się obronić tezy, że np.15-latek nie rozumie własnych działań agresywnych, bo sam był niegdyś ofiarą agresji czy odtrącenia emocjonalnego. On dobrze wie, co robi, i wie również, że to jest niedopuszczalne, ale neutralizuje ewentualne wyrzuty sumienia poprzez przyjęcie jakiejś upraszczającej ideologii, w której człowieka, bliźniego degraduje się do poziomu rzeczy, szmaty, szczura, pasożyta itp. ${ }^{15}$.

\section{Podsumowanie}

Każda osoba nieletnia, która dopuszcza się czynu karalnego, mimo iż często musiała znosić trudy swojego dorastania w patologicznej rodzinie, musi liczyć się z konsekwencjami swoich aspołecznych zachowań. Środowisko zewnętrze i wspólna integracja społeczna stanowią swego rodzaju wzór do naśladowania właściwych zachowań, relacji interpersonalnych i ukierunkowane są na działania zgodne z prawem. Wybór niewłaściwej ścieżki życiowej, skutkujący łamaniem prawa i nieprzestrzeganiem norm społecznych, jest zazwyczaj celowym i świadomym wyborem. Sam fakt dorastania w patologicznej rodzinie nie może być usprawiedliwieniem, a jedynie powodem do próby pomocy tej osobie i jej resocjalizacji. Przyczyn zachowań aspołecznych dzieci i młodzieży jest wiele, głównie są to alkoholizm rodziców, bieda, negatywna przeszłość któregoś z rodziców, które rodzą przemoc w rodzinie. W rodzinach dotkniętych przemocą domową problemy dziecka są bagatelizowane, wręcz niezauważalne, a rodzice skupiają się wyłącznie na swoich sprawach i problemach. Takie osoby są często niepilnowane, pozostawione bez kontroli rodzicielskiej, spędzają większość swojego czasu poza

15 L. Pytka, Niewydarzeni, sfrustrowani, agresywni, dz. cyt., s. 70. 
domem, z rówieśnikami, którzy nierzadko dopuszczają się czynów karalnych i negatywnie na nich wpływają. Często osoby, które raz spróbowały dokonać czynu karalnego i nie poniosły z tego tytułu żadnych konsekwencji (prawnych czy wychowawczych), zatrącają się w błędnym kole swoich aspołecznych zachowań, z którego nie tak łatwo się wydostać. Łatwy zarobek czy wzbudzenie szacunku wśród rówieśników zajmują kluczową rolę i stają się motywatorem do dalszych działań przestępczych. Dlatego też socjalizacja człowieka musi odbywać się już od najmłodszych lat, gdyż tylko wtedy człowiek buduje podstawy swojej moralności, przyzwoitości i uczciwości. Z wiekiem postawy te wzmacniają się, pozwalając rozwijać i kształtować własne wartości, które zostaną uzewnętrznione w środowisku społecznym.

\section{Bibliografia}

Cudak S., Znaczenie więzi emocjonalnych $w$ rodzinie dla prawidłowego funkcjonowania dzieci, „Pedagogika Rodziny” (2012) nr 2/4, s. 31-39.

Dąbrowska A., Rodzina patologiczna w przestrzeni życiowej młodych dorastających, „Studia nad Rodziną” (2009) nr 13/1-2 (24-25), s. 205-213.

https://encyklopedia.pwn.pl/haslo/patologie-spoleczne;3955029.html (12.09.2018).

Kochel J., Wprowadzenie do antropologii pedagogicznej. W kręu pedagogii katolickiej, Opole 2018.

Koźdub M., Osobowość antyspołeczna, http://zaburzeniaosobowosci.pl/antyspoleczna.html (09.09.2018).

Kudlak G., Instytucjonalna resocjalizacja nieletnich. Wyzwania i perspektywy rozwoju, Warszawa 2016.

Panusiuk B., Przemoc i agresja jako specyficzna forma reakcji człowieka na stres życia i pracy, w: Przemoc dzieci i młodzieży w perspektywie polskiej transformacji ustrojowej, red. J. Papież, A. Płukis, Toruń 1999, s. 81-94.

Pytka L., Niewydarzeni, sfrustrowani, agresywni, w: Przemoc dzieci i młodzieży w perspektywie polskiej transformacji ustrojowej, red. J. Papież, A. Płukis, Toruń 1999, s. 69-70.

Sitarczyk M., Ojciec w percepcji nieletnich sprawców przestępstw, w: Dziecko jako ofiara i sprawca przemocy. Przestępczość nieletnich, red. B. Gull, M. Wysocka-Pleczyk, Kraków 2009, s. 161-171 . 
Sołtysiak T., Zachowania patologiczne młodego pokolenia, w: Resocjalizacja. Zagadnienia prawne, społeczne i metodyczne, red. A. Jaworska, Kraków 2009, s. 51-59.

Wolińska J. M., Agresywność młodzieży. Problem indywidualny i społeczny, Lublin 2000.

Urban B., Zaburzenia w zachowaniu i przestępczość młodzieży, Kraków 2000. 